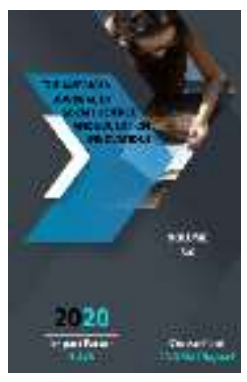

\section{The Education Innovations In The Development Of The Young Learners' English-Speaking Skills In Uzbekistan}

Journal Website: http://usajournalshub.c om/index,php/tajssei

Copyright: Original content from this work may be used under the terms of the creative commons attributes 4.0 licence.

\author{
Mukaddaskhon Ogay
}

Head Of The Multimedia Department, Innovation Centre, Uzbek State University Of World Languages, Uzbekistan

\title{
ABSTRACT
}

This article examines and compares the requirements for the development of English-speaking skills of the young learners in Uzbekistan, Russia, Kazakhstan and Turkey. According to the requirements of the state standards for teaching English in these countries, the author analyzes the effectiveness of using multimedia applications for teaching foreign languages in primary school. The comparison of curricula and state standards of these 4 countries revealed the similar requirements for teaching English at the initial stage, such as the use of new technologies and non-traditional methods in the teaching process. The analysis is carried out on the basis of a questionnaire survey of English language teachers, the young learners and their parents in order to identify the most effective activities that motivate and increase the interest of primary school children in learning English. The survey results show that not only teachers and the young learners, but also their parents are interested in using the multimedia applications in language learning, as their children enjoy learning the language through games, as well as songs, videos, animations and interactive activities.

\section{KEYWORDS}

Teaching English, speaking, the young learners, multimedia application, activities. 


\section{INTRODUCTION}

What problem is the research focused on? The State educational standard for teaching foreign languages determines the level of the foreign language knowledge and is a normative and legislative document for the creation of curricula and programs, textbooks and teaching resources.

The relevance of the use of new technologies, namely, multimedia applications to the textbooks, is dictated by the pedagogical needs to increase the effectiveness of teaching foreign languages in primary school, the need to develop independent learning skills, a creative approach to learning, the formation of critical thinking, and the young learners' ability to use the language in conversation.

Along with the regulatory and legislative documents of the Republic of Uzbekistan, when drawing up the state standards, for the first time in history of teaching foreign languages the Common European Framework of Reference (CEFR) was considered and applied.

Currently, CEFR is an international system for assessing the level of proficiency in a foreign language. According to this system, skills are correlated with certain criteria given to the three main levels of language proficiency (Aelementary, category of basic proficiency, Bself-sufficient, category of independent proficiency, C-fluent, category of language proficiency level).

The young learners after graduating from ordinary primary school, according to the requirements of the State educational standards, must reach A1 level, and A1 + level at the end of specialized primary school with indepth study of the English language. English language specialists from the UK and the USA were involved in the creation the last version of the standards for all stages of the education system in Uzbekistan. Currently, at the end of Grade 4, the young learners must overcome the $\mathrm{A} 1$ level in speaking and listening skills. Writing and reading skills at the A1 level, according to the latest requirements of the Ministry of Public Education, will be tested at the end of Grade 6. This is due to the fact that in Grade 1 the young learners practice English orally in the form of games, and only in Grade 2 they begin to study the alphabet, and read and write in English.

And that is the real problem which must be solved. How to teach a language to young learners without reading and writing? How to get them interested in learning a new language, when the educational process itself is completely new for them and requires a lot of diligence and effort. At a time when children want to relax and play, they have to study and memorize a lot of new material in all subjects, and a foreign language, in addition to everything, is not yet understandable by ear. It was necessary to create a textbook and teaching material that would attract the attention of young learners. Since the main form of the lesson should be based on listening and speaking, it became necessary to move away from the traditional methods of teaching a foreign language.

\section{THE MAIN PART}

How was the problem studied? 
So, after studying the world experience in teaching a foreign language in primary school, discussing and taking into account the opinion of experts, a new curriculum was created which was relevant to the State standards.

To know how it works in different countries where English is taught as a foreign language, the syllabi of Uzbekistan, Russia, Kazakhstan and Turkey were compared.

Let's look at what a young learner should know and be able to do in order to reach the $\mathrm{A} 1$ level in speaking, in accordance with the requirements of the State educational standards of Uzbekistan.

\begin{tabular}{|c|c|c|c|}
\hline \multicolumn{3}{|c|}{ Competencies } & Know / be able to \\
\hline \multirow{4}{*}{ 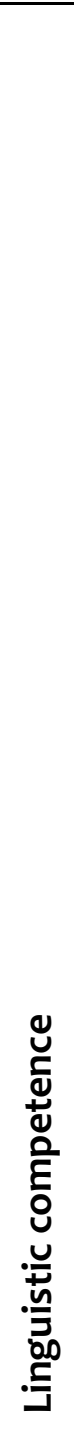 } & 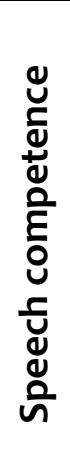 & 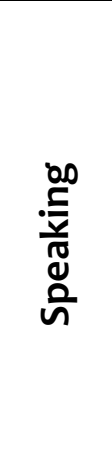 & $\begin{array}{l}\text { Dialogue } \\
\text { Request and provide information. } \\
\text { Request for help. } \\
\text { Ask and answer simple questions. } \\
\text { Monologue } \\
\text { Describe where you live, your family, friends and } \\
\text { acquaintances. } \\
\text { Introduce yourself and talk about your likes and dislikes. } \\
\text { Make a short presentation on a familiar topic. }\end{array}$ \\
\hline & \multirow{3}{*}{ 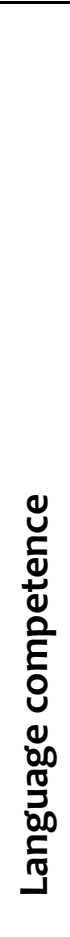 } & 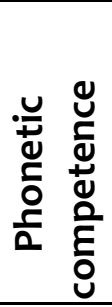 & $\begin{array}{l}\text { Pronounce all the sounds of the FL accurately. } \\
\text { Use stress in words and expressions correctly. } \\
\text { Use intonation patterns in accordance with the communicative } \\
\text { situation. }\end{array}$ \\
\hline & & 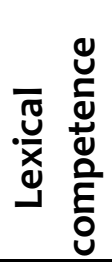 & $\begin{array}{l}\text { Use the learned lexical units in context. } \\
\text { Use basic thematic vocabulary in communicative situations. } \\
\text { Recognize and use some international words and borrowings. }\end{array}$ \\
\hline & & 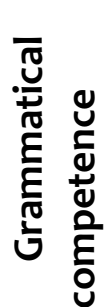 & $\begin{array}{l}\text { Use simple grammatical and syntactic constructions in } \\
\text { communicative situations. } \\
\text { Connect words and phrases using "and". } \\
\text { Coordinate sentences correctly and represent events in } \\
\text { descriptions and stories using verbs and adverbs. }\end{array}$ \\
\hline
\end{tabular}

Table 1. Requirement for A1 level of speaking [10] 
One of the main principles is to immerse the young learners in the target language. The immersion can be carried out using multisensory channels: auditory, visual, kinesthetic. The children should be actively involved in all activities.

In teaching a foreign language to the young learners, speaking in combination with facial expressions, gestures and movements serves as a means of realizing the oral form of communication. Most of the grammatical structures of the English language, according to J. Asher, can be conveyed through the imperative mood and actions, using exercises from the group of Total Physical Response activities [1]
For young learners, it is not enough to understand just words about reality or explanations. They must create reality through their own experience and imagination. J. Piaget called this process of language acquisition the construction of reality. The children are not interested in how the language works, but they are very interested in understanding and expressing their interests in the target language. They can puzzle out the language through looking, pointing, touching, etc. [8]

The curriculum for Grade 1 consists of 66 hours a year, and for Grades 2,3,4- 68 hours a year.

\begin{tabular}{|l|l|l|}
\hline \multicolumn{1}{|c|}{$\#$} & Units & \multicolumn{1}{|c|}{ Topics } \\
\hline 1. & Unit 1 & We learn English \\
\hline 2. & Unit 2 & My day \\
\hline 3. & Unit 3 & I help my parents \\
\hline 4. & Unit 4 & Jobs \\
\hline 5. & Unit 5 & All about Uzbekistan \\
\hline 6. & Unit 6 & Welcome to the party! \\
\hline 7. & Unit 7 & Holidays \\
\hline 8. & Unit 8 & Shops \\
\hline 9. & Unit 9 & At the market \\
\hline 10. & Unit 10 & Sport \\
\hline 11. & Unit 11 & At the doctor \\
\hline 12. & Unit 12 & Travelling \\
\hline 13. & Unit 13 & Great Britain \\
\hline 14. & Unit 14 & The world of fairy tales \\
\hline 15. & Unit 15 & $\begin{array}{l}\text { Additional (in the multimedia application for revising the } \\
\text { whole year learning material) }\end{array}$ \\
\hline
\end{tabular}

Table 2. The Units of the textbook "Kids' English"- 4 
The American Journal of Social Science and Education Innovations

Doi: https://doi.org/10.37547/tajssei/Volume02Issue08-11

\begin{tabular}{|c|c|}
\hline Curriculum / 68 hours a year & Kids' English, Grade 4 \\
\hline $\begin{array}{c}\text { Ability to talk about oneself, his/her } \\
\text { family and friends }\end{array}$ & Units 1-14 \\
\hline $\begin{array}{c}\text { Ability to speak, ask questions (about } \\
\text { sports, for example) }\end{array}$ & Units 1,2,10 \\
\hline Ability to make a request & Units 2,6,8,9,13 \\
\hline $\begin{array}{l}\text { Ability to participate in micro- } \\
\text { conversations (dialogues, monologues) on } \\
\text { familiar topics }\end{array}$ & Units 1-14 \\
\hline $\begin{array}{l}\text { Ability to answer the questions about the } \\
\text { texts he/she read and heard, and to retell the } \\
\text { texts }\end{array}$ & Units 1-14 \\
\hline
\end{tabular}

Table 3. Practice of speaking in Grade 4[4]

As we see, each single Unit of the textbook practices speaking skill development.

In Uzbekistan the textbook “Kid's English" is used in teaching English to young learners. It consists of a Pupils' book (with Parents' Corner), Teacher's book, Workbook, and multimedia application with songs, videos, audios, cartoons, and animated and interactive exercises.

- To master A1 level young learners should be able to communicate on the following topics:

- Everyday topics (personal information, family information, spending free time, etc.).

- Social topics (social contacts with the outside world).

- Educational topics (school subjects and attitudes towards them, etc.).

- Socio-cultural topics (historical, geographical, climatic, cultural and other features of the English-speaking countries and Uzbekistan).

Let's look at the requirements for the development of English-speaking skills of young learners in the Russian Federation.

Although the Russian Federation (RF) has adopted a unified program for beginning teaching a foreign language to primary schoolchildren from Grade 2, some schools, such as schools specialized in the English language learning, or gymnasiums introduce learning English from Grade 1.

The English language teaching program is also designed for the perception and reproduction of oral English speech in the first year of study (Grade 2), and the 2 nd or 3 rd years of study (Grades 3-4) contain writing and reading. [3] 
The American Journal of Social Science and Education Innovations (ISSN - 2689-100x)

Published: August 10, 2020 | Pages: 69-78

Doi: https://doi.org/10.37547/tajssei/Volume02Issue08-11

\begin{tabular}{|l|l|l|}
\hline$\#$ & Units & Topics \\
\hline 1 & Unit 1 & Seasons and weather \\
\hline 2 & Unit 2 & Your home \\
\hline 3 & Unit 3 & City and countryside \\
\hline 4 & Unit 4 & Telling stories \\
\hline 5 & Unit 5 & A good time with your family \\
\hline 6 & Unit 6 & Shopping \\
\hline 7 & Unit 7 & School \\
\hline
\end{tabular}

Table 4. The Units of the textbook "Enjoy English"- 4

The most popular textbook among teachers of English is "Enjoy English", which consists of a Pupils' book, Workbook, and multimedia application with songs, audio monologues and dialogues. The state educational standard of primary education establishes the following requirements for the foreign language knowledge: the acquisition of basic communication skills in oral and written form; mastering the rules of speech and non-speech behavior; possession at an elementary level of oral and written speech in a foreign language; the formation of a friendly attitude and tolerance towards speakers of another language on the basis of acquaintance with the life of their peers in other countries.

Let's look at the requirements for the development of English-speaking skills of young learners in Kazakhstan.

Since 2016, secondary schools in Kazakhstan have gradually switched to teaching a foreign language according to a new educational standard.This standard sets the goal for teachers of foreign languages to teach learners not academic language. The main idea is to develop their critical thinking, the ability to apply the language in practice, communication skills, individual and teamwork.[12]

\begin{tabular}{|l|l|l|}
\hline$\#$ & Units & Topics \\
\hline 1 & Unit 1 & Kazakhstan in the world of sports \\
\hline 2 & Unit 2 & Values in myths and legends \\
\hline 3 & Unit 3 & Treasures \\
\hline 4 & Unit 4 & Professions and ways of communication \\
\hline 5 & Unit 5 & Hot and cold \\
\hline 6 & Unit 6 & Healthy World \\
\hline 7 & Unit 7 & Travel into space \\
\hline 8 & Unit 8 & Cars \\
\hline
\end{tabular}

Table 4. The Units of the textbook "Smiles"- 4 
Primary schools in Kazakhstan use the textbook "Smiles", which consists of a Pupils' book, Workbook, Grammar workbook, Teacher's book, cards, and multimedia application with songs, rhymes, and audio exercises.

The development of speaking skills in grade 4 include the ability to formulate basic statements about oneself, the ability to ask and answer questions, describe objects and events using basic words and phrases, and express likes and dislikes.

And now, let's look at the requirements for the development of English-speaking skills of young learners in the Turkish Republic.
M. Alkan and M. Arslan in their research consider a new curriculum. The researchers focused on the English Language Curriculum for Second Grade Primary School, as it is the first program implemented at the second-grade level in public schools in the Republic of Turkey. Summarizing the characteristics of the second grade English curriculum, the authors found that the focus is on listening and speaking skills. Reading and writing skills are as limited as possible. Based on the results of the research of these authors, the main goal of the English lessons in primary schools in the Republic of Turkey is for young learners to master the language for real communication.

\begin{tabular}{|l|l|l|}
\hline$\#$ & Units & Topics \\
\hline 1 & Unit 1 & Classroom Code of Conduct \\
\hline 2 & Unit 2 & Nationality \\
\hline 3 & Unit 3 & Cartoon characters \\
\hline 4 & Unit 4 & Free time \\
\hline 5 & Unit 5 & My day \\
\hline 6 & Unit 6 & Having fun with science \\
\hline 7 & Unit 7 & Professions \\
\hline 8 & Unit 8 & Clothing \\
\hline 9 & Unit 9 & My friends \\
\hline 10 & Unit 10 & Food and drink \\
\hline
\end{tabular}

Table 4. From Grade-4 Curriculum [13]

After graduating from Grade 4 the young learners will be able to talk about their basic needs and feelings, express the feelings and needs of others, describe their friends and other people (family members, teachers, etc.), ask and answer questions about the physical characteristics of other people using adjectives, simple phrases, questions and answers. 


\section{RESULTS}

What are the main findings?

Having analyzed the state standards of these countries for teaching English in primary school, the author identified the following similarities:

- Activities such as group or pair work, project work with presentation, roleplaying games, painting, storytelling, work with tables and graphs are actively used by English teachers in these countries to develop speaking skills,

- According to the new requirements for teaching English in these countries, the focus is on listening and speaking skills development,

- $\quad$ Reading and writing skills are limited.

The content of multimedia applications for the Kids' English textbooks is Videos, Audios, Animation tasks (e.g. Magic box), Interactive activities (e.g. Jump a word, Naughty words), Cartoons, and Songs. [5]

The multimedia applications to the English textbooks in Russia, Kazakhstan and the Republic of Turkey also include audio and video exercises, songs and poems in English.

It is worth emphasizing that the videos offered in the multimedia application in primary schools of Uzbekistan are a short video instruction on how to do this or that exercise. Most of the videos show examples of dialogues or group work.

In order to understand how effective a multimedia application is, a group of
English teachers, young learners, and their parents were offered to answer a series of questions.

192 teachers from different regions of Uzbekistan and with the working experience ranged from 1 to more than 20 years noted that:

- they use the multimedia app in classes to support their instructions and to introduce the active vocabulary- $98 \%$,

- the songs help young learners to raise their speaking ability- $91 \%$,

- it's effective to use the multimedia to organize the pair/group activities- $88 \%$,

- the interactive activity "Naughty words" can help practice the correct use of sentence structure in speech$89 \%$,

- the multimedia app can be used for knowledge assessment- 93\%,

- watching cartoons can help my pupils to practice creating and presenting stories (with the heroes of the cartoons)- 94\%,

- the app is an effective tool for parents to help their children to learn English$86 \%$.

225 parents of Grade-4 learners participated in the survey. Among the answers we can highlight the following:

- $\quad 97 \%$ are sure their children like English,

- $\quad 95 \%$ note that their children like watching cartoons, singing songs in English, 
- $\quad 92 \%$ say they can help their children revise the words using the app,

- $\quad 90 \%$ believe that the app to the textbook can help their children learn English faster,

- $96 \%$ offer to create more educational apps for young learners.

As for the young learners, 225 children from different schools of Uzbekistan took part in the survey. Here are their answers:

- $95 \%$ of them like English classes,

- $86 \%$ can speak about themselves, their family and friends in English,

- $87 \%$ like watching cartoons and fairy tales in English classes,

- $88 \%$ can play "Interview" after watching the instruction videos,

- $94 \%$ like listening to and singing songs in English classes,

- 90\% like playing "Jump a word" activity in the app,

- $89 \%$ like repeating words in the "Magic box" activity.

\section{CONCLUSION}

Comparing the content of the multimedia applications to the textbooks used in primary school of the 4 countries, the following can be distinguished:

-the most popular activities included in the multimedia applications are songs, videos, audio of short and simple dialogues and monologues, and educational cartoons as well.
J. Dayag in his research shows that both young professionals and experienced English teachers integrate multimedia into their teaching. [2]

The results of the questionnaire show that the English teachers in Uzbekistan use the multimedia applications to the textbooks as well. They note the effectiveness of the activities in the app for improving speaking skills of the young learners.

The emergence and development of multimedia technologies and their use in teaching, creates a favorable platform for reforming the model of teaching English. The positive role of multimedia in promoting young learners' activity and initiative. The use of multimedia has greatly contributed to the growth of interest in the English language learning. [8]

The answers of the learners and their parents allow us to conclude that the activities used in the multimedia applications, such as "Naughty words", "Jump a word", "Magic box", as well as songs, cartoons, videos and audios increase young learners' interest and motivation for learning English.

\section{REFERENCES}

1. Asher, J. "What is TPR?" in TPR-World. Retrieved on 2012-05-29

2. Dayag, J.D. 2016. Integrating multimedia in teaching English to Omani learners// The journal of teaching English for specific and 
academic purposes. Vol. 4, No.1, Special Issue. pp. 171-180

3. Federal state educational standard of general primary education. 2019. Ministry of Education of the Russian Federation.

https://www.preobra.ru/attachments/1 I

4. Khan S., Juraev, L., Ogay, M. “Kid's English”// P/h Uzbekistan. 2016.

5. Multimedia application to the textbook Kids' English for Grade 4. 2016. Tashkent

6. Ogay, M. 2020. A system of activities for the formation of young learners' speaking skill using multimedia applications in English classes// Modern Education. Tashkent. No. 5, Pp.10-17

7. Ogay, M. 2020. Use of multimedia in teaching English to the the young learners// European Journal of Research and Reflection in Educational Sciences. Progressive Academic Publishing. UK. Vol. 8. No. 4, pp.1-10

8. Pandey, M. 2014. The use of multimedia in teaching and learning English language. https://www.academia.edu/5649576/U se_of_Multimedia_in_English_Langua ge_Teaching
9. Piaget, J. The Construction of Reality in the Child. http://www.marxists.org/reference/su bject/philosophy/works/fr/piaget2.htm

10. Resolution of the Cabinet of Ministers of the Republic of Uzbekistan. On the approval of the State educational standard for foreign languages of continuous education system. Tashkent. 2013. No.124

11. Resolution of the Cabinet of Ministers of the Republic of Uzbekistan. On approval of the State educational standard for secondary and secondaryspecialized, professional education. 2017. No.187

12. Resolution of the Minister of Education and Science of the Republic of Kazakhstan. Typical curriculum on English for Grades 1-4 of the primary education level. 2018. No. 199

13. T.R.Ministry of Education. English Course Curriculum. Primary and Secondary Schools 2, 3, 4, 5, 6, 7 and 8th Grades. Ankara. 2018 